\title{
Pahang River Community Satisfaction towards Their Quality of Life: The Case of Community in Pekan, Pahang
}

\author{
Hayrol Azril Mohamed Shaffril (Corresponding author) \\ Laboratory of Sustainable Development and Agriculture Extension, Institute for Social Science Studies \\ Universiti Putra Malaysia, Putra Infoport, 43400 Serdang, Selangor Darul Ehsan, Malaysia \\ Tel: 60-3-8947-1870Ｅ-mail: majudesa.desa@gmail.com \\ Sulaiman Md. Yassin \\ Laboratory of Sustainable Development and Agriculture Extension, Institute for Social Science Studies \\ Universiti Putra Malaysia, Putra Infoport, 43400 Serdang, Selangor Darul Ehsan, Malaysia \\ Tel: 60-3-8947-1863 E-mail: sulaimanyassin@gmail.com
}

Md. Salleh Hassan

Laboratory of Sustainable Development and Agriculture Extension, Institute for Social Science Studies Universiti Putra Malaysia, Putra Infoport, 43400 Serdang, Selangor Darul Ehsan, Malaysia

Tel: 60-3-8947-1851Ｅ-mail: mdsalleh@putra.upm.edu.my

Mohd Shahwahid Othman

Department of Hospitality and Recreation, Faculty of Economy and Management

Universiti Putra Malaysia, 43400 Serdang, Selangor Darul Ehsan, Malaysia

Tel: 60-3-8946-7658Ｅ-mail: mohdshahwahid@gmail.com

Bahaman Abu Samah

Laboratory of Sustainable Development and Agriculture Extension, Institute for Social Science Studies Universiti Putra Malaysia, Putra Infoport, 43400 Serdang, Selangor Darul Ehsan, Malaysia

Tel: 60-3-8947-1852Ｅ-mail: drbas@ace.upm.edu.my

Asnarulkhadi Abu Samah

Department of Social and Development Science, Faculty of Human Ecology

Universiti Putra Malaysia, 43400 Serdang, Selangor Darul Ehsan, Malaysia

Tel: 60-3-8946-7066 E-mail: asnarul@putra.upm.edu.my

Siti Aisyah Ramli

Laboratory of Sustainable Development and Agriculture Extension, Institute for Social Science Studies Universiti Putra Malaysia, Putra Infoport, 43400 Serdang, Selangor Darul Ehsan, Malaysia

Tel: 60-3-8947-1870 E-mail: syah_amal@yahoo.com.my

Received: June 21, 2011

doi:10.5539/ass.v7n12p43
Accepted: July 13, $2011 \quad$ Published: December 1, 2011

URL: http://dx.doi.org/10.5539/ass.v7n12p43

The research is financed by Research University Grant Scheme (Scheme 1) sponsored by Universiti Putra Malaysia. 


\begin{abstract}
We examined the satisfaction of Pahang River community who live in Pekan towards certain aspects of their quality of life. What is the level of satisfaction of this community towards their quality of life; low, moderate or high? This is a quantitative study where questionnaire was used to gain the data needed. A total of 300 villagers had been selected as the respondents for this study. All of the respondents selected were the villagers that live along Pahang River in the area of Pekan, Pahang. SPPS was used to run the appropriate analyses. Overall, our analyses revealed that the Pahang River community living in Pekan have a moderate satisfaction towards their quality of life. However, further analysis employed, have indicated that Pahang River community in Pekan do have a high level of satisfaction towards four aspects of quality of life namely social involvement and relationship, safety at areas, home condition and education. Development in Pekan which includes the improvements along Pahang River need to continuously take place as it can have a huge impact on the Pekan community especially those who live along the Pahang River.
\end{abstract}

Keywords: Quality of life, Rural development, Satisfaction, Pahang River

\title{
1. Introduction
}

\subsection{What is quality of life?}

Quality of life, happiness, wellbeing, and utility are often seen as one and they are frequently used interchangeably. Quality of life (QOL) can be defined as an individual's perception of their position in life in the context of the culture and value systems in which they live and in relation to their goals, expectations, standards, and concerns (WHOQOL Group, 1993). The QOL Research Unit of University of Colorado in the other hand defines QOL as

"The degree to which a person enjoys the important possibilities of his/her life. Possibilities result from the opportunities and limitations each person has in his/her life and reflect the interaction of personal and environmental factors. Enjoyment has two components: the experience of satisfaction and the possession or achievement of some characteristic, as illustrated by the expression: "She enjoys good health." Three major life domains are identified: Being, Belonging, and Becoming"

Stiglitz et al. (2010) has emphasized on several points for defining and measuring the QOL. First is the people. They emphasize on things that considered as important in their daily life, and on the environment in which they develop. This does not means the communities and institutions are neglected, but it requires evaluating them in virtue of what they bring to the QOL of the people participating in them. This view also involves focusing on the "ends" of various human activities, while recognizing that their achievement can matter both intrinsically and instrumentally (i.e. to achieve some other goal).

Second is recognition that human condition is not the same and is different. This variety signals that societal well-being determined by both the aggregate level of the various items that shape people's lives and on how they are disseminated in society. The relative importance attributed to these two aspects is related to alternative conceptions of social justice.

Third, QOL can be measured based on numerous dimensions, and there is no ranking of importance of the dimensions. QOL can cover various aspects (as opposed to scalar nature of income) and this increases the complexity of the analyses and raises a number of measurement issues. These pertain to whether the instruments used suit the community studied, how to distinguish the importance of each dimension, what is the best indicators to use to describe accomplishments in the various dimensions, how to present these indicators (e.g. in their raw form, or by standardizing them in various ways), and whether and how to aggregate them.

Last is a focus on the present, rather than on the QOL of future generations; while the sustainability of QOL is an important issue. If QOL is defined as they suggested, then the best person to justify their level of QOL is they themselves (Nord, 2001).

\subsection{Aspects to be measured for quality of life}

There is a huge number of QOL studies have been completed. Through these studies, they have come out with a number of aspects on QOL that need to be focused. Table 1 presents some of the recent studies conducted locally and internationally on the aspects to be emphasized for measuring the QOL.

The government of Malaysia has come out with its own indicator of QOL. There are two version included in Table 1; the QOL version of 1999 and the QOL version of 2004. The only difference between these two versions is the element of culture and leisure has been added to the 2004 version. The selection of the areas for Malaysian QOL Index (MQOL) was based on the importance and how best it reflects the particular area as well as the 
availability of data. The major references for developing the MQOL were World Development Indicator, World Bank, Human Development Index, United Nation and IMD International (NikAzman, 2010).

The Calvert-Henderson Quality of Life Indicators was first developed 18 years back in 1994, for the purpose of organizing, synthesizing and analysing a host of statistics on the social, economic and environmental state of the nation. This indicator then allows the data to be converted into understandable indicators that able to aid the community in comprehending the complex phenomena. The dimensions of QOL in this indicator measured consist of 12 indicators which are education, employment, energy, environment, health, human rights, income, infrastructure, national security, public safety, recreation and shelter.

The West Wicklow Rural Communities Consultation Project is an idea created for the purpose of involving with communities in West Wicklow in order to ascertain the key themes and issues that influence their QOL. The general objective of this project is to identify the social exclusion issues and needs that are common to dissolved communities of West Wicklow with a view to inform the identification of appropriate responses. A total of eight dimensions have been emphasized in this project namely transportation, child minding provision and play facilities, access to health care, road safety, environmental services, education and training, information and advisory services, supporting local voluntary efforts.

The Canadian Policy Research Network (CPRN) has developed one of major reports in QOL study. The report entitled Indicators of Quality of Life in Canada: A Citizens' Prototype was invented based on themes and indicators developed from 40 dialogues that were conducted across Canada in 2000. Within this indicator, a total of nine main dimensions of QOL have been identified namely political right and general values, health, education, environment, social programs/condition, personal well-being, community, economy and employment and government.

The Consultation, Research and Intelligence Team Strategy and Performance Division, Bristol City Council (2010) has conducted the Quality of Life in Your Neighbourhood Survey which started in 2001 and provided an annual snapshot of QOL in Bristol. The survey contains questions related to the community local neighbourhood, their lifestyle, health and personal details including ethnic origin, age and postcode of their home address. The traffic light symbols were used where the change colour of the traffic lights provide an indicator estimate (measured in the 2010 survey) based on confidence limits. Ward and neighbourhood partnership area analysis and equalities analyses have been used in this study.

\subsection{Objective of the Study}

The objective of this study is to measure the level of satisfaction of Pahang River community living in Pekan towards their QOL. To measure the level of satisfaction this study has developed a total of seven QOL dimensions (which later discussed at the methodology part).

\subsection{The current situation on quality of life of the rural community in Malaysia}

Rural development has continuously been emphasized by the Malaysian authorities. To effectively improve the socio-economic development of the rural areas, the government of Malaysia has set two stages of rural development transformation and evolution. The first stage of development took almost 47 years to be completed (1957 to 1994).Two policies which were the Pre New Economy Policy and New Economy Policy have been established under this stage.The main focus of rural development set by the government was providing basic infrastructure, agriculture development based on main commodities, equity development, efforts on poverty alleviation, land and regional development and dissemination of subsidy. The second stage of the development which is still in progress (1994-2020) is based on the New Philosophy and Policy on Rural Development. In this stage, the main focus is to achieve the status of developed country in 2020. Similar to the first stage of development, this stage also requires two new policies which are National Development Policy and National Vision Policy. Compared to the first two policies, the newer two policies are more emphasizing on balanced development, human resource development, regionalization of land development authorities, an improved quality of services for better quality of life, achieving sustainable development, poverty alleviation amongst lower income group, developing attractive, developed and profitable rural areas and focus of rural development on specific groups. These two development stages have already reflected their success on the rural community. The most obvious one is the increase on the income of the rural community. In 1999, it was noted that the monthly income per month per rural household was RM1,718 compared to RM2,545 in 2009. To further develop the rural areas, in the recent Tenth Malaysia Plan (10MP), the focus of development will be on the physical, social and economic in which the rural communities are among the main beneficiaries. In terms of education, the government efforts to strengthen the education aspects at the rural areas and widening the chances of getting 
higher education among the rural students have already shown its impact when almost half million of the rural students were offered places at the university for pursuing their studies at bachelor level.

Moreover, in the period of four years (2006 to 2009) a total of 1,419.26 km of new and repaired roads have been made available in the rural areas. Interestingly a total of 1927 rural clinics have been established by the government in order to uplift the health status of the rural community. In terms of electric and water supply, under the Program of Rural Electric Supply, in 2010 a total of 14,140 houses (which before this were facing electric supply problems) have been provided with this energy supply while for water supply a total of 15,383 new houses in the rural areas have been provided with this supply (Ministry of Rural and Regional Development, 2011). To further improve Malaysian quality of life including those in the rural areas, the Malaysian government has introduced 6 NKRAs (National Key Result Areas) which are 1) reduction of crime rates; 2) combating corruption; 3) widening access to affordable and quality education areas; 4) raising the living standard of the poor; 5) improving the infrastructure in rural areas and 6) improving public transport in the medium term.

All of the facts stated are the evidences of the emergent impacts from the decades of rural development programs, but besides these successes, does the rural community satisfied with their current status of quality of life?

\subsection{The Pahang River}

Pahang River is one of the longest rivers in Malaysia. It covers $459 \mathrm{~km}$ long and drains an area of $25,600 \mathrm{~km}^{2}$. Three quarters of this basin area is located in Pahang while a quarter of the basin area is located in Negeri Sembilan. The Pahang River originated from Mount Tahan in Pahang. This river system starts to flow in the south east and south direction from north passing along major towns such as Kuala Lipis, Jerantut and Temerloh and finally turning eastward at Mengkarak in the central south flowing through Pekan town near the coast before discharging into the South China Sea. A number of big towns can be found along the Pahang River basin which include Pekan, Marang, Temerloh, Jerantut, Kuala Lipis, Raub and Bentung. Pahang River is also rich with its historical values. A number of historical sites can be found along Pahang River. Pahang River is one of the routes used by Hang Tuah to bring TunTeja to Malacca. Furthermore, there are historical sites such as Lubuk Pahang Tomb which consist the tombs of Sultan Abdul Jamil, Datuk Budiman and Puteri Buluh Betong. There, a building for the British Resident was erected. It was later converted into a palace for the Sultan. Now it is the Sultan Abu Bakar Muzium. Pahang River still plays active roles to the industry and community daily life. Pahang River delivers more than 120 mld of water, via the Public Works Department to meet the demand of domestic and industrial sectors, particularly in urban regions and it also provides water resources to the community and also agriculture industry particularly paddy.

\section{Methodology}

A total of 300 respondents have been selected randomly for this study. The respondents selected were among the villagers that live along Pahang River. The instrument used for this study was a developed questionnaire. The questionnaire was first pre-tested before the actual data collection took place. The questionnaire consist of seven aspects of QOL which were 1) social involvement and relationship; 2) safety at areas; 3) home condition; 4) education; 5) physical environment; 6) financial and job security; and 7) infrastructure facilities. From these seven aspects, a total of 51 items have been questioned to the respondents. For each of the question asked, the respondents were given a five likert-like scale answer ranging from 1) strongly satisfy; 2) not satisfied; 3) moderately satisfied; 4) satisfied and 5) strongly satisfied. Survey was conducted with the respondents where the services of trained and experienced enumerators were used to gain the data needed. SPSS was used for the purpose of analyses where analyses such as frequency, percentage mean and standard deviation were employed to describe the data of the study.

\section{Results}

\subsection{Respondents' demographic data}

Based on the results gained in Table 2, it can be seen that majority of the respondents were female (53.7\%). Slightly more than half of the respondents $(50.3 \%)$ were among those aged between 41 to 60 years old. Majority of the respondents can be categorized as the lower educated group as majority of them only possessed SPM/SPMV/MCE level of education (32.7\%), followed by those who possessed primary school level of education (28.7\%) and PMR/SRP/LCE level of education (21.7\%). Nearly one third of the respondents (32.3\%) were housewives while $17.3 \%$ of them working in agriculture related works. More than one third of the respondents $(35.3 \%)$ earned between RM501 to RM1000 per month and only one third of the respondents $(33.3 \%)$ were found still in the group of poverty level. With the mean of 32.23 years for the period of staying in the area, we can consider that majority of the respondents interviewed were the "senior villagers". More than two 
fifths of the respondents $(48.0 \%)$ who lived more than $11 \mathrm{~km}$ away from the nearest city while more than a quarter of the respondents $(29.5 \%)$ lived 251 to 500 meters from the Pahang River. It also can be seen that a large majority of the respondents (74.35) were married and $45.3 \%$ of the respondents have 3 to 5 family members within their homes.

\subsection{Overall level of $Q O L$}

To get the mean score for the overall level of QOL, a cumulative value from the seven aspects of QOL studied namely 1) social involvement and relationship; 2) safety at the areas; 3) home condition; 4) education; 5) physical environment; 6) financial and job security and 7) infrastructure facilities was gained. Based on the results presented in Table 3, it can be concluded that the respondents studied have a moderate level of QOL based on the mean score of 3.65 (from the maximum mean score of 5.00).

\subsection{The aspects of $Q O L$ studied}

Table 4 shows the overall level of one of the aspects of QOL studied; social involvement and relationship. To gain the overall mean score, all of the mean scores of the 9 items studied in this aspect were gained. The overall mean score recorded for this aspect was 4.06, thus it shows that respondents studied do have a high level of social involvement and relationship.

Table 5 clarifies to us specifically each of the items studied for the aspect of social involvement and relationship. It can be seen that four of the items managed to record a mean score more than 4.00 and the items were 1) free from domestic violence $(M=4.54)$; 2) Interaction with neighbour $(M=4.53)$; 3) General conversation with family members $(M=4.49)$ and 4$)$ Activities with family members $(M=4.44)$. However, one item was detected to record a mean score lower than 3.00 and the item was 5) Involvement in Sport Association $(\mathrm{M}=2.60)$.

Based on the mean score of 3.93 for the overall level of safety at the areas, it can be concluded that the respondents studied have a high level of QOL on this aspect. Majority of the respondents (72.3\%) have a high level of satisfaction on safety at the areas while $27.4 \%$ of the respondents have a moderate level of satisfaction towards this aspect (Table 6).

A total of six items had been posed to the respondents in order to reveal their satisfaction towards safety at their areas. Results presented in Table 6 revealed that only one item managed to record mean score more than 4.0. The item is "calmness at your neighbourhood" $(\mathrm{M}=4.02)$. The item of preparation for disaster (ex: flood; accidents) recorded the lowest mean score ( $\mathrm{M}=3.48)$ (Table 7).

For overall level of satisfaction towards home condition, the overall mean score recorded was 3.81 and it can be concluded that the respondents have a high satisfaction towards this aspect. Nearly two thirds of the respondents $(61.3 \%)$ were found to have a high level of satisfaction towards their home condition compared to the respondents who have a moderate satisfaction towards their home condition (38.7\%). Interestingly, there were no respondents that were detected to have a low level of satisfaction towards their home condition (Table 8).

A total of eleven items were questioned to the respondents for the aspect of satisfaction towards their home condition. Based on the results presented in Table 9, it can be seen that ten out of eleven items asked recorded a high mean score (3.68-5.00). The highest mean score was recorded by item of 1) services of electric supply to your home $(\mathrm{M}=4.18)$ followed by 2$)$ location of your home $(\mathrm{M}=4.12)$. The third highest mean score was recorded by item of "toilet facilities at your home" $(M=267)$. The lowest mean score was recorded by item of "garbage collection services from your home" $(\mathrm{M}=2.67)$.

Education is indeed an important aspect of life. It is a key for future success of all types of community, but do Pahang River community in Pekan have a high level of satisfaction towards the aspect of education? Table 10 has the answer. Based on the overall mean score recorded $(\mathrm{M}=3.71)$, it can be concluded that the respondents studied do have a high level of satisfaction towards this aspect. It is interesting to know that none of the respondents were detected to have a low level of satisfaction towards the education aspect.

Table 11 portrays specifically each of the items used to measure respondent's satisfaction towards the education aspect. A total of five items were used and it can be concluded that three items were detected to have a high mean score (3.68-5.00) and the items were 1) The current condition of the school infrastructure $(\mathrm{M}=4.06) ; 2)$ The way of teachers teaching at school; and 3) Opportunity to continue study at university. However, there are two items that were detected to have a moderate mean score and the items were 1) Educational attainment that you have been received/receiving (including seminar, courses) $(\mathrm{M}=3.49)$ and 2) The current level of discipline among school students $(\mathrm{M}=3.16)$. 
Another aspect studied to measure satisfaction towards quality of life is the physical environment. Based on the results presented in Table 12, it can be seen that the respondents studied have a moderate level of satisfaction towards this aspect. Further analyses have shown to us that a total of $61.9 \%$ of the respondents have a moderate level of satisfaction towards this aspect while $39.0 \%$ of the respondents were detected to have a high level of satisfaction towards this aspect.

Table 13 has presented seven items used to measure the satisfaction towards the physical environment. The highest mean score was recorded by item of "noise at your neighbourhood' $(\mathrm{M}=4.05)$. The second highest mean score was recorded by item of "cleanliness of the air" $(\mathrm{M}=3.99)$ while the third highest mean score was recorded by the item of "foul-odour within housing area" $(\mathrm{M}=3.90)$. Regarding to the cleanliness of the Pahang River, majority of the respondents moderately satisfied with the cleanliness of the river and a total of $29.3 \%$ of the respondents satisfied with the cleanliness of the river.

In a lot of studies, financial factor is indeed a key to have a better QOL. But does this factor also have influence on Pahang River community? Based on the data gained, it can be revealed that the respondents studied do have a moderate level of satisfaction towards the financial and job security aspects. However, despite the overall moderate level of satisfaction score, it can be detected that some of the respondents (37.0\%) do have a high level of satisfaction towards this aspect (Table 14).

Table 15 has portrayed to us specifically each of the items used to measure satisfaction towards QOL. A total of six items have been used and interestingly all of the items indicated a moderate level of satisfaction. The highest mean score was recorded by the item of "relationship with office colleague" $(\mathrm{M}=3.66)$, followed by the item of "work environment" $(M=3.65)$ and satisfaction towards job status $(M=3.61)$. The lowest mean score was recorded by the item of "easiness to get loan" $(\mathrm{M}=2.96)$.

The last aspect studied focus on satisfaction towards the infrastructure facilities. A large majority of the respondents $(70.7 \%)$ had a moderate level of satisfaction towards this aspect. A total of $18.0 \%$ respondents were detected to have a high level of satisfaction towards this aspect and a total of $11.3 \%$ of the respondents had a low level of satisfaction towards the infrastructure facilities provided (Table 16).

To gain respondents satisfaction towards the physical environment, a total of five items were questioned to the respondents. It can be noted that one item managed to score a high level of satisfaction and the item was "worship places" $(\mathrm{M}=4.33)$; two items were managed to score a moderate level of satisfaction and the items were 1) "Post Office/Bank/Police Station ( $\mathrm{M}=3.65) ; 2$ ) "Recreational places" (Table 17).

\section{Discussion}

To gain a better QOL is a dream of everyone. A better QOL is an indicator of satisfaction, happiness and success of an individual. Pahang River community in Pekan possess a better QOL and this study has proven it. Based on the moderate level of satisfaction towards QOL, it gives us a sign that the Pahang River Community in Pekan are moving towards a better QOL. The aspect of social involvement and relationship has recorded the highest mean score. Four items have managed to record the highest mean score and all of the items have something to do with a positive relationship with family members and neighbours and this indicates that efforts done by the Ministry of Women, Family and Community Development in terms of strengthening the family and neighbourhood ties have already reflected its impacts on Pahang River community in Pekan. Family and neighbours relationship influence on quality of life has been discussed in the previous studies done by Pearce and Axinn (1998) and Faulkner and Chang (2007). Faulkner and Chang (2007) for example have done a study that indicated the importance of family relationship on QOL in which they have stressed that open family communication is one of the keys to have a better QOL. Safety at the areas is one of the aspects that recorded a high level of satisfaction. Items such as calmness at your neighbourhood areas, safety from crime, security services and safety at your neighbourhood have signalled a high level of satisfaction. This is a good sign as it can assist the Malaysian government in achieving one of their main National Key Result Areas (NKRA) which is reduction of crime rates (Marzbali et al., 2011 and Henry, 2006). Henry (2006) for example has concluded that reduction of crime indeed have influence on QOL when he stressed that the QOL enjoyed by local community can be improved tremendously if a palpable positive change in the sense of safety and civility throughout the areas can be created.

Home condition is another aspect that recorded a high level of satisfaction. It is interesting to discover that 10 out of 11 items used recorded a high level of satisfaction. Home is a best place for us to relax and release all of our tension and indeed have something to do with our QOL (Horan, 2001 and Kyle and Dunn, 2006). Horan et al. (2001) for example, have proven that people with a better QOL are always found to stay at a bigger house, have basic facilities, near to the city and equipped with additional accommodation. Apart from this, it is good to know that Pahang River community in Pekan do have a high level of satisfaction towards education aspect. This is not 
surprising as there is a growing number of educational institutions especially the higher learning institution around Pekan and among the famous ones are University Malaysia Pahang (UMP), Pahang Islamic College Sultan Ahmad Shah (KIPSAS), Community College of Pekan and many more. The growing number means that there are bigger chances for them and their family members to pursue their education to the highest level. Results gained from this study is in line with what have been found by Shin (1986); Cupples et al. (1996); Ross and Willgen (1997) and Lasheras et al. (2001).Ross and Wiligen (1997) for example have stressed that education improves well-being because it increases access to nonalienated paid work and economic resources that increase their level of QOL. Even though aspects such as physical environment, financial and job security and infrastructure facilities recorded a moderate level of satisfaction, it should not be a major concern. It is expected that satisfaction towards QOL among Pahang River Community in Pekan will increase in these three aspects as the development in Pekan continuously take its course. The emergence of industrial areas in Pekan will continue to provide jobs and stable income for the locals while the new highway that links Pekan and Kuantan is expected to flourish the economic activities between these two cities and this is possible as it has been proven by previous studies (Fischer and Amekudzi, 2011 and Ro, 2002).

\section{Conclusion}

We do know that in Malaysia as a whole, a lot of studies have been conducted to investigate the QOL of the rural community, but up to this date, we do believe that we are the only one that have made a study specifically on the Pekan community that live along Pahang River in Malaysia. Based on the results gained, we conclude that the Pahang River community especially those who live in Pekan do have a moderate level of satisfaction towards QOL. Further analyses have proven that the Pahang River community in Pekan do have a high level of satisfaction towards the aspect of social involvement and relationship, safety at areas, home condition and education. We also can conclude that the Pahang River community in Pekan do have a moderate level of satisfaction towards the aspect of physical environment, financial and job security and infrastructure facilities. It is not a big concern as these three QOL aspects scored a moderate level of satisfaction as persistent and continuous development projects will for sure increase their satisfaction towards their QOL. It is interesting to know that none of the aspects were detected to score a low level of satisfaction among the Pahang River community live in Pekan. It is expected that this study could raise a lot of future researches and discussions on the river community QOL and it is hoped to lead others to further examine the QOL concept as applied to human development progress in Malaysia and the region. This study also concluded that the Pahang River community in Pekan can become an important component of the population which can be the focus of home-grown and community-driven development.

\section{References}

Calvert Group Ltd and Henderson, H. (2000-2006). Calvert-Henderson Quality of Life Indicators. [Online] Available: http://www.calvert-henderson.com/

Canadian Policy Research Network (CPRN). (2001). Indicators of Quality of Life in Canada:A Citizens' Prototype. Summary of Results of Public Dialogue Sessions and Prototype of National Indicators.

Consultation, Research and Intelligence Team Strategy and Performance Division, Bristol City Council. (2010). Quality of Life in Bristol: Quality of Life in Your Neighbourhood Survey Results 2009. [Online] Available: http://www.bristol.gov.uk/ccm/cms-service/stream/asset/?asset_id=34582046

Cupples, M.E., McKnight, A, O'Neil, C, and Normand, C. (1996). The Effects of Personal Health Education on Quality of Life of Patient with Angina in General Practice. Health Education Journal, 55 (1): 75-83. http://dx.doi.org/10.1177/001789699605500107

Department for International Development. (1999). Sustainable Livelihood Guidance Sheet. [Online] Available: http://www.ennonline.net/pool/files/ife/section2.pdf

Faulkner, M.S. and Chang, L. (2007). Family Influence on Self-Care, Quality of Life, and Metabolic Control in School-Age Children and Adolescents with Type 1 Diabetes. Journal of Paediatric Nursing, 22(1): 59-68. http://dx.doi.org/10.1016/j.pedn.2006.02.008

Fischer, J.M. and Amekudzi, A. (2011). Quality of Life, Sustainable Civil Infrastructure, and Sustainable Development: Strategically Expanding Choice. Journal of Urban Planning and Development, 137, 39. http://dx.doi.org/10.1061/(ASCE)UP.1943-5444.0000039

Henry, V.E. (2006). Compstat Management in the NYPD: Reducing Crime And Improving Quality Of Life In New York City. [Online] Available: http://www.unafei.or.jp/english/pdf/RS_No68/No68_11VE_Henry1.pdf

Horan, M.E., Muller, J.J. Winocur, S. and Barling, N. (2001). Quality of Life in Boarding Houses and Hostels: A Residents' Perspective. Journal of Community Health, 37(4): 323-334.

Kyle, T, and Dunn, J.R. (2006). Effects of Housing Circumstances on Health, Quality of life and Healthcare Use for People with Severe Mental Illness: A Review. Journal of Health Society Care Community, 16(1):1-15. http://dx.doi.org/10.1111/j.1365-2524.2007.00723.x 
Lasherasm C., Paterson, A.M. Casado, C. and Fernandez, S. (2001). Effects of Education on the Quality of Life, Diet and Cardiovascular Risk Factor in Elderly Spanish Community Population. Journal of Experience Aging Research, 27 (3): 257-270. http://dx.doi.org/10.1080/036107301300208691

Malaysian Quality of Life Index. (1999). [Online] Available: http://202.75.7.57/New\%20Folder/publication/mqli99/All.pdf

Malaysian Quality of Life Index. (2004). [Online] Available: http://www.epu.gov.my/c/document_library/get_file?p_l_id=10364\&folderId=122841\&name=DLFE-4717.pdf Marzbali, M.H., Abdullah, A. and Abdul Razak, N. (2011). A Review of the Effectiveness of Crime Prevention by Design Approaches towards Sustainable Development. Journal of Sustainable Development, 4(1): 160-172.

Minitsry of Rural and Regional Development. (2011). Information on Malaysia Rural Statistics. [Online] Available: http://www.rurallink.gov.my/resources

NikAzman, N.A.M. (2010). Quality of Malaysian Quality of Life. [Online] Available: http://www.mier.org.my/presentations/archives/pdf/qualityoflife.pdf

Pearce, L.D. and Axinn, W.G. (1998).The Impact of Family Religious Life on the Quality of Mother-Child Relations. Journal of American Sociological Review, 63(6): 810-828. http://dx.doi.org/10.2307/2657503

Ro, J. (2002). Infrastructure Development in Korea. Paper presented at: The PEO Structure Specialists Meeting Infrastructure Development in the Pacific Region September 23-24, 2002, Osaka, Japan.

Ross, C.E. and Willigen, M.W. (1997). Education and Subjective Quality of Life. Journal of Health and Social Behavior, 38: 275-297. http://dx.doi.org/10.2307/2955371

Shin, D.C. (1986). Education and the Quality of Life in Korea and the United States: A Cross Cultural Perspective. Journal of Public Opinion, 50 (3): 360-370. http://dx.doi.org/10.1086/268989

The Stiglitz Commission on the Measurement of Economic Performance and Social Progress. (2010). Objective Indicators of Quality of Life. [Online] Available: http://www.dgins-sofia2010.eu/pdocs/Insee\%20paper\%20Objective\%20Indicators\%20of\%20Quality\%20of\%201 ife.pdf

The West Wicklow Rural Community Consultation Project. (2004). Addressing Quality of Life issues in Rural

[Online] Available: http://www.wicklow.ie/Apps/WicklowBeta/Publications/CommEnterprise/quality\%20of\%20life.pdf

Table 1 . Aspects of quality of life to be measured

\begin{tabular}{|l|l|}
\hline Name of the researcher/organization & Aspects of QOL emphasized \\
\hline Malaysian Quality of Life Index (MQLI) (2004) & $\begin{array}{l}\text { Income and distribution, working life, transport and } \\
\text { communication, education, housing, environment, family life, } \\
\text { social participation, public safety and culture and leisure. }\end{array}$ \\
\hline Malaysia Quality of Life Index (MQLI) (1999) & $\begin{array}{l}\text { Income and distribution, working life, transport and } \\
\text { communication, health, education, housing, environment, } \\
\text { family life, social participation and public safety }\end{array}$ \\
\hline The Calvert-Henderson Quality of Life Indicators & $\begin{array}{l}\text { Education, employment, energy, environment, health, human } \\
\text { rights, income, infrastructure, national security, public safety, } \\
\text { recreation and shelter }\end{array}$ \\
\hline $\begin{array}{l}\text { The West Wicklow Rural Communities Consultation } \\
\text { Project (2004) }\end{array}$ & $\begin{array}{l}\text { Transportation, Child minding provision and play facilities, } \\
\text { access to health care, road safety, environmental services, } \\
\text { education and training, information and advisory services, } \\
\text { supporting local voluntary efforts }\end{array}$ \\
\hline Canadian Policy Research Network (CPRN) (2001) & $\begin{array}{l}\text { Democracy, health, education/learning, environment, social } \\
\text { conditions, community, personal well-being, } \\
\text { employment/economy and government }\end{array}$ \\
\hline $\begin{array}{l}\text { Consultation, Research and } \\
\text { Intelligence Team } \\
\text { Strategy and Performance Division, Bristol City } \\
\text { Council (2010). }\end{array}$ & $\begin{array}{l}\text { Health and wealth inequality, stronger and safer community, } \\
\text { sustainable prosperity, higher aspiration for children; young } \\
\text { people and families, climate change, regeneration and } \\
\text { affordable housing, transport and digital connectivity, culture } \\
\text { and creativity, satisfaction with public services }\end{array}$ \\
\hline
\end{tabular}


Table 2. Demography data of the respondents

\begin{tabular}{|c|c|c|c|c|}
\hline Level & Frequency & Percentage & Mean & SD \\
\hline \multicolumn{5}{|l|}{ Gender } \\
\hline Male & 139 & 46.3 & & \\
\hline Female & 161 & 53.7 & & \\
\hline Age & & & 49.34 & 14.81 \\
\hline$<40$ years & 78 & 26.0 & & \\
\hline $41-60$ years & 151 & 50.3 & & \\
\hline$>61$ years & 71 & 23.7 & & \\
\hline \multicolumn{5}{|l|}{ Level of education } \\
\hline Never been to school & 25 & 8.3 & & \\
\hline Primary School & 86 & 28.7 & & \\
\hline PMR/SRP/LCE & 65 & 21.7 & & \\
\hline SPM/SPMV/MCE & 98 & 32.7 & & \\
\hline Skills certificates & 4 & 1.3 & & \\
\hline STPM/Diploma & 18 & 6.0 & & \\
\hline Degree/Master/PhD & 4 & 1.3 & & \\
\hline \multicolumn{5}{|l|}{ Job category } \\
\hline Housewife & 97 & 32.3 & & \\
\hline Self-employed & 43 & 14.3 & & \\
\hline Agriculture related & 51 & 17.0 & & \\
\hline Retiree & 25 & 8.3 & & \\
\hline Private sector & 35 & 11.7 & & \\
\hline Government sector & 27 & 9.0 & & \\
\hline Others & 22 & 7.3 & & \\
\hline Income per month & & & 1356.16 & 1412.90 \\
\hline$\leq \mathrm{RM} 500$ & 67 & 22.3 & & \\
\hline RM501-RM1000 & 106 & 35.3 & & \\
\hline RM1001-RM1500 & 46 & 15.3 & & \\
\hline RM1501-RM2500 & 53 & 17.8 & & \\
\hline$>\mathrm{RM} 2,501$ & 28 & 9.3 & & \\
\hline \multicolumn{5}{|l|}{ Poverty Level (PL) } \\
\hline Below PL (<RM720) & 100 & 33.3 & & \\
\hline Above PL (>RM721) & 200 & 66.7 & & \\
\hline Period of staying at the village & & & 39.23 & 20.98 \\
\hline$<25$ years & 84 & 28.0 & & \\
\hline $26-50$ years & 120 & 40.0 & & \\
\hline$\geq 51$ years & 96 & 32.0 & & \\
\hline Distance to the nearest city & & & 13.39 & 9.81 \\
\hline$\leq 5 \mathrm{~km}$ & 48 & 16.0 & & \\
\hline $6-10 \mathrm{~km}$ & 108 & 36.0 & & \\
\hline$\geq 11 \mathrm{~km}$ & 144 & 48.0 & & \\
\hline Distance to nearest river & & & .846 & .676 \\
\hline$<250$ meter & 79 & 26.3 & & \\
\hline 251-500 meter & 89 & 29.7 & & \\
\hline 501-1000 meter & 67 & 22.3 & & \\
\hline $1 \mathrm{~km}-2 \mathrm{~km}$ & 65 & 21.7 & & \\
\hline
\end{tabular}




\section{Marital status}

Single

Married

Divorced
41

223

36

40

136

68

56
13.7

74.3

12.0

\section{Number of family members}

$1-2$

3-5

$\geq 8$
$40 \quad 13.3$
136

45.3

22.7

18.7

Table 3. Overall level of quality of life

\begin{tabular}{lllll}
\hline QOL & Frequency & Percentage & M & SD \\
\hline Overall level of QOL & & & $\mathbf{3 . 6 5}$ & $\mathbf{3 3 5}$ \\
Low (1-2.33) & 0 & 0 & \\
Moderate (2.34-3.67) & 149 & 49.3 & \\
High (3.68-5.00) & 151 & 50.7 &
\end{tabular}

Table 4. Overall level of satisfaction towards social involvement and relationship

\begin{tabular}{|c|c|c|c|}
\hline $\begin{array}{l}\text { Social involvement } \\
\text { relationship }\end{array}$ & and & 4.06 & .457 \\
\hline Low (1-2.33) & 2 & .7 & \\
\hline Moderate (2.34-3.67) & 74 & 24.6 & \\
\hline High (3.68-5.00) & 224 & 74.7 & \\
\hline
\end{tabular}

Table 5. Items used to measure the respondents social involvement and relationship

\begin{tabular}{|l|l|l|l|l|l|l|l|}
\hline & $\begin{array}{l}\text { Strongly } \\
\text { not } \\
\text { satisfied }\end{array}$ & $\begin{array}{l}\text { Not } \\
\text { satisfied }\end{array}$ & $\begin{array}{l}\text { Moderately } \\
\text { satisfied }\end{array}$ & Satisfied & $\begin{array}{l}\text { Strongly } \\
\text { satisfied }\end{array}$ & Mean & S.D \\
\hline Free from domestic violence & 1.1 & 0.4 & 2.9 & 34.9 & 60.7 & 4.54 & 0.68 \\
\hline Interaction with neighbour & 0.2 & 0.3 & 3.9 & 37.4 & 58.1 & 4.53 & 0.61 \\
\hline $\begin{array}{l}\text { General conversation with } \\
\text { family members }\end{array}$ & 0.3 & 0.6 & 6.2 & 35.7 & 57.2 & 4.49 & 0.67 \\
\hline $\begin{array}{l}\text { Activities with family } \\
\text { members }\end{array}$ & 0.6 & 1.3 & 6.7 & 35.9 & 55.6 & 4.44 & 0.73 \\
\hline $\begin{array}{l}\text { Satisfaction towards } \\
\text { recreation/entertainment } \\
\text { activities }\end{array}$ & 3.1 & 5.1 & 21.2 & 30.3 & 40.2 & 3.99 & 1.05 \\
\hline $\begin{array}{l}\text { Involvement in charity } \\
\text { activities }\end{array}$ & 3.6 & 4.7 & 16.8 & 47.7 & 27.3 & 3.91 & 0.97 \\
\hline $\begin{array}{l}\text { Involvement in } \\
\text { consumerism and } \\
\text { environmental preservation }\end{array}$ & 5.8 & 6.9 & 20.6 & 44.0 & 22.8 & 3.71 & 1.07 \\
\hline $\begin{array}{l}\text { Involvement In political } \\
\text { party }\end{array}$ & 11.4 & 14.9 & 24.9 & 34.4 & 14.3 & 3.25 & 1.21 \\
\hline $\begin{array}{l}\text { Involvement in Sport } \\
\text { Associations }\end{array}$ & 29.7 & 17.9 & 21.0 & 25.6 & 5.9 & 2.60 & 1.30 \\
\hline
\end{tabular}


Table 6. Overall level of safety at the areas

\begin{tabular}{lllll}
\hline Quality of life aspects & Frequency & Percentage & M & SD \\
\hline Safety at the areas & & & $\mathbf{3 . 9 3}$ & $\mathbf{. 6 1 9}$ \\
Low (1-2.33) & 1 & .3 & \\
Moderate (2.34-3.67) & 82 & 27.4 & & \\
High (3.68-5.00) & 217 & 72.3 & & \\
\hline
\end{tabular}

Table 7. Items used to measure aspect of safety at the areas

\begin{tabular}{|l|l|l|l|l|l|l|l|}
\hline & $\begin{array}{l}\text { Strongly } \\
\text { not } \\
\text { satisfied }\end{array}$ & $\begin{array}{l}\text { Not } \\
\text { satisfied }\end{array}$ & $\begin{array}{l}\text { Moderately } \\
\text { satisfied }\end{array}$ & Satisfied & $\begin{array}{l}\text { Strongly } \\
\text { satisfied }\end{array}$ & Mean & S.D \\
\hline $\begin{array}{l}\text { Calmness at your } \\
\text { neighbourhood }\end{array}$ & 0.1 & 2.4 & 14.7 & 61.3 & 21.4 & 4.02 & 0.68 \\
\hline $\begin{array}{l}\text { Safety from crime (self and } \\
\text { property) }\end{array}$ & 0.1 & 3.1 & 18.7 & 59.0 & 19.1 & 3.94 & 0.71 \\
\hline $\begin{array}{l}\text { Security services (Ex: } \\
\text { Police) }\end{array}$ & 1.4 & 5.2 & 13.2 & 58.9 & 21.2 & 3.93 & 0.82 \\
\hline $\begin{array}{l}\text { Safety your } \\
\text { neighbourhood }\end{array}$ & 0.6 & 5.3 & 19.9 & 56.3 & 17.9 & 3.86 & 0.79 \\
\hline $\begin{array}{l}\text { Enforcement of law for } \\
\text { security }\end{array}$ & 5.3 & 6.2 & 22.3 & 50.4 & 15.7 & 3.65 & 0.99 \\
\hline Existing law fister (ex: & 9.4 & 8.4 & 24.2 & 40.7 & 17.2 & 3.48 & 1.15 \\
\hline $\begin{array}{l}\text { Preparation for disas } \\
\text { flood, accident) }\end{array}$ & & 6.7 & 21.6 & 51.2 & 15.1 & 3.64 & 1.00 \\
\hline
\end{tabular}

Table 8. Overall level of satisfaction towards home condition

\begin{tabular}{lllll}
\hline Quality of life aspects & Frequency & Percentage & M & SD \\
\hline Home condition & & & $\mathbf{3 . 8 1}$ & $\mathbf{5 0 2}$ \\
Low (1-2.33) & 0 & 0 & & \\
Moderate (2.34-3.67) & 116 & 38.7 & & \\
High (3.68-5.00) & 184 & 61.3 & & \\
\hline
\end{tabular}

Table 9. Items used to measure the aspect of home condition

\begin{tabular}{|l|l|l|l|l|l|l|l|}
\hline & $\begin{array}{l}\text { Strongly } \\
\text { not } \\
\text { satisfied }\end{array}$ & $\begin{array}{l}\text { Not } \\
\text { satisfied }\end{array}$ & $\begin{array}{l}\text { Moderately } \\
\text { satisfied }\end{array}$ & Satisfied & $\begin{array}{l}\text { Strongly } \\
\text { satisfied }\end{array}$ & Mean & S.D \\
\hline $\begin{array}{l}\text { Services of electric supply } \\
\text { to your home }\end{array}$ & 0.2 & 1.7 & 6.9 & 62.3 & 28.9 & 4.18 & 0.64 \\
\hline Location of your home & - & 1.7 & 11.0 & 60.8 & 26.6 & 4.12 & 0.65 \\
\hline $\begin{array}{l}\text { Toilet facilities in your } \\
\text { home }\end{array}$ & 0.1 & 1.4 & 11.1 & 61.6 & 25.8 & 4.11 & 0.65 \\
\hline Comfort in your home & - & 3.0 & 11.1 & 60.9 & 25.0 & 4.08 & 0.69 \\
\hline Spaces in your home & 0.2 & 2.9 & 12.4 & 59.3 & 25.1 & 4.06 & 0.71 \\
\hline $\begin{array}{l}\text { Services of water supply to } \\
\text { your home }\end{array}$ & 0.7 & 5.0 & 8.8 & 59.4 & 26.1 & 4.05 & 0.78 \\
\hline Your home surroundings & 0.1 & 2.9 & 14.2 & 58.6 & 24.2 & 4.04 & 0.71 \\
\hline Rooms in your home & 0.2 & 4.6 & 15.9 & 54.4 & 24.9 & 3.99 & 0.78 \\
\hline $\begin{array}{l}\text { Availability of roads to your } \\
\text { home }\end{array}$ & 0.6 & 4.6 & 15.2 & 54.9 & 24.8 & 3.99 & 0.80 \\
\hline $\begin{array}{l}\text { Your home drainage and } \\
\text { sewerage system }\end{array}$ & 4.2 & 10.7 & 15.9 & 48.6 & 20.7 & 3.71 & 1.04 \\
\hline $\begin{array}{l}\text { Garbage collection services } \\
\text { from your home }\end{array}$ & 32.3 & 14.1 & 17.4 & 26.4 & 9.7 & 2.67 & 1.41 \\
\hline
\end{tabular}


Table 10. Overall level of education aspect

\begin{tabular}{lllll}
\hline Quality of life aspects & Frequency & Percentage & M & SD \\
\hline Education & & & $\mathbf{3 . 7 1}$ & $\mathbf{5 0 3}$ \\
Low (1-2.33) & 0 & 0 & & \\
Moderate (2.34-3.67) & 162 & 54.0 & & \\
High (3.68-5.00) & 138 & 46.0 & & \\
\hline
\end{tabular}

Table 11. Items used to measure satisfaction towards education aspect

\begin{tabular}{|l|l|l|l|l|l|l|l|}
\hline & $\begin{array}{l}\text { Strongly } \\
\text { not } \\
\text { satisfied }\end{array}$ & $\begin{array}{l}\text { Not } \\
\text { satisfied }\end{array}$ & $\begin{array}{l}\text { Moderately } \\
\text { satisfied }\end{array}$ & Satisfied & $\begin{array}{l}\text { Strongly } \\
\text { satisfied }\end{array}$ & Mean & S.D \\
\hline $\begin{array}{l}\text { The current condition of the } \\
\text { school infrastructure }\end{array}$ & - & 1.8 & 13.3 & 61.9 & 23.0 & 4.06 & 0.66 \\
\hline $\begin{array}{l}\text { The way of teachers } \\
\text { teaching at school }\end{array}$ & 0.2 & 1.6 & 15.0 & 64.2 & 19.0 & 4.00 & 0.65 \\
\hline $\begin{array}{l}\text { Opportunity to continue } \\
\text { study at university }\end{array}$ & 0.2 & 3.0 & 18.8 & 57.2 & 20.8 & 3.95 & 0.73 \\
\hline $\begin{array}{l}\text { Educational attainment that } \\
\text { you have } \\
\text { received/receiving been } \\
\text { (including seminar, courses) }\end{array}$ & 11.7 & 7.1 & 21.2 & 40.3 & 19.7 & 3.49 & 1.22 \\
\hline $\begin{array}{l}\text { The current level of } \\
\text { discipline among school } \\
\text { students }\end{array}$ & & 24.2 & 35.2 & 34.1 & 4.7 & & 3.16 \\
\hline
\end{tabular}

Table 12. Overall level of satisfaction towards physical environment

\begin{tabular}{lllll}
\hline Quality of life aspects & Frequency & Percentage & M & SD \\
\hline Physical environment & & & $\mathbf{3 . 6 2}$ & $\mathbf{4 4 0}$ \\
Low (1-2.33) & 0 & 0 & & \\
Moderate (2.34-3.67) & 183 & 61.0 & & \\
High (3.68-5.00) & 117 & 39.0 & & \\
\hline
\end{tabular}

Table 13. Items used to measure satisfaction towards the physical environment

\begin{tabular}{|l|l|l|l|l|l|l|l|}
\hline & $\begin{array}{l}\text { Strongly } \\
\text { not } \\
\text { satisfied }\end{array}$ & $\begin{array}{l}\text { Not } \\
\text { satisfied }\end{array}$ & $\begin{array}{l}\text { Moderately } \\
\text { satisfied }\end{array}$ & Satisfied & $\begin{array}{l}\text { Strongly } \\
\text { satisfied }\end{array}$ & Mean & S.D \\
\hline $\begin{array}{l}\text { Noise at your } \\
\text { neighbourhood area }\end{array}$ & 0.2 & 2.6 & 12.4 & 61.9 & 22.9 & 4.05 & 0.69 \\
\hline Cleanliness of the air & 0.1 & 3.9 & 13.6 & 61.4 & 21.0 & 3.99 & 0.72 \\
\hline $\begin{array}{l}\text { Odor at your surrounding } \\
\text { areas }\end{array}$ & 1.6 & 6.0 & 14.8 & 56.0 & 21.7 & 3.90 & 0.86 \\
\hline Drinking water & 0.7 & 8.4 & 31.0 & 44.8 & 15.1 & 3.65 & 0.86 \\
\hline Cleanliness of the river & 5.4 & 26.7 & 34.6 & 29.3 & 4.0 & 3.00 & 0.97 \\
\hline Waste disposal system & 17.7 & 15.2 & 23.8 & 37.2 & 6.2 & 2.99 & 1.22 \\
\hline $\begin{array}{l}\text { Forest/recreation part/mount } \\
\text { hill etc }\end{array}$ & 32.7 & 13.8 & 22.0 & 26.7 & 4.9 & 2.57 & 1.31 \\
\hline
\end{tabular}


Table 14. Overall level of satisfaction towards financial and job security

\begin{tabular}{lllll}
\hline Quality of life aspects & Frequency & Percentage & M & SD \\
\hline Financial and job security & & & $\mathbf{3 . 3 3}$ & $\mathbf{7 2 9}$ \\
Low (1-2.33) & 25 & 8.3 & & \\
Moderate (2.34-3.67) & 164 & 54.7 & & \\
High (3.68-5.00) & 111 & 37.0 & & \\
\hline
\end{tabular}

Table 15. items used to measure satisfaction towards financial and job security

\begin{tabular}{|l|l|l|l|l|l|l|l|}
\hline & $\begin{array}{l}\text { Strongly } \\
\text { not } \\
\text { satisfied }\end{array}$ & $\begin{array}{l}\text { Not } \\
\text { satisfied }\end{array}$ & $\begin{array}{l}\text { Moderately } \\
\text { satisfied }\end{array}$ & Satisfied & $\begin{array}{l}\text { Strongly } \\
\text { satisfied }\end{array}$ & Mean & S.D \\
\hline $\begin{array}{l}\text { Relationship with office } \\
\text { colleague }\end{array}$ & 6.2 & 6.1 & 22.0 & 46.7 & 19.0 & 3.66 & 1.05 \\
\hline Work environment & 5.3 & 6.7 & 23.1 & 47.8 & 17.1 & 3.65 & 1.01 \\
\hline $\begin{array}{l}\text { Satisfaction towards job } \\
\text { status }\end{array}$ & 3.8 & 8.3 & 27.4 & 44.3 & 16.1 & 3.61 & 0.98 \\
\hline Job security/stability & 5.3 & 8.9 & 25.9 & 42.6 & 17.3 & 3.58 & 1.04 \\
\hline Financial status & 3.9 & 9.0 & 31.3 & 41.1 & 14.6 & 3.53 & 0.98 \\
\hline $\begin{array}{l}\text { Ability to pay medical } \\
\text { services by private health } \\
\text { experts }\end{array}$ & 9.8 & 12.2 & 30.3 & 35.2 & 12.4 & 3.28 & 1.13 \\
\hline Easiness to get loan & 22.2 & 12.0 & 23.4 & 32.0 & 10.4 & 2.96 & 1.32 \\
\hline
\end{tabular}

Table 16. Overall level of satisfaction towards infrastructure facilities

\begin{tabular}{lllll}
\hline Quality of life aspects & Frequency & Percentage & M & SD \\
\hline Infrastructure facilities & & & $\mathbf{3 . 1 0}$ & $\mathbf{. 6 2 5}$ \\
Low (1-2.33) & 34 & 11.3 & \\
Moderate (2.34-3.67) & 212 & 70.7 & \\
High (3.68-5.00) & 54 & 18.0 & & \\
\hline
\end{tabular}

Table 17. Items used to measure satisfaction towards infrastructure facilities

\begin{tabular}{|l|l|l|l|l|l|l|l|}
\hline & $\begin{array}{l}\text { Strongly } \\
\text { not } \\
\text { satisfied }\end{array}$ & $\begin{array}{l}\text { Not } \\
\text { satisfied }\end{array}$ & $\begin{array}{l}\text { Moderately } \\
\text { satisfied }\end{array}$ & Satisfied & $\begin{array}{l}\text { Strongly } \\
\text { satisfied }\end{array}$ & Mean & S.D \\
\hline Worship places & 0.3 & 1.7 & 8.0 & 45.1 & 44.9 & 4.33 & 0.72 \\
\hline Post Office/Bank/Police etc & 1.4 & 6.4 & 29.7 & 50.7 & 11.8 & 3.65 & 0.82 \\
\hline $\begin{array}{l}\text { Public transportation } \\
\text { services }\end{array}$ & 22.0 & 17.2 & 22.1 & 29.8 & 8.9 & 2.86 & 1.30 \\
\hline Recreational places & 28.9 & 19.3 & 23.8 & 22.7 & 5.3 & 2.56 & 1.26 \\
\hline Public toilet facilities & 45.7 & 13.9 & 18.4 & 18.2 & 3.8 & 2.21 & 1.29 \\
\hline
\end{tabular}

